Session 1413

\title{
A Web-Based Case Study for the Chemical Engineering Capstone Course
}

\author{
Lisa Bullard, Patricia Niehues, Steven W. Peretti, Shannon H. White \\ North Carolina State University
}

One of the most daunting tasks in teaching the capstone design class is to develop suitable projects. Some departments may not have faculty with industrial experience; other departments may not be located near industrial partners to provide hands-on experience to the students; and other departments may lack faculty with deep expertise in specific areas such as biotechnology. North Carolina State University is developing, testing, and disseminating case studies for use in capstone senior chemical engineering design courses. Three web-based case studies developed at North Carolina State University will be presented. The projects involve modifications to (1) a vaccine facility, (2) a citric acid/nutriceutical facility, and (3) an ammonia plant. Supporting materials have been developed for each case study, including a problem statement, a detailed solution that is considered to be exemplary by an industrial reviewer and a report by the NCSU faculty member responsible for the case study of the difficulties and typical errors that might be encountered as the students carry out the design assignment.

A web site devoted to the case studies has been established which contains all of the supporting material, including tutorials covering many of the technical aspects of the projects, and a full project solution (only accessible to faculty). This paper will review the development of the case studies, and then focus on how the information can be accessed and used, as well as presentation of some exemplary results.

\section{Introduction}

Leading chemical engineering faculty, in a series of three workshops entitled New Frontiers in Chemical Engineering Education, have identified a need for case studies to support the unifying curricular themes of molecular transformation, multi-scale analysis, and systems approaches. ${ }^{5}$ As a result of this workshop series, case studies are sought that provide real world context - including aspects of safety, economics, ethics, regulations, intellectual property, market/societal needs). In addition, the desired case studies would provide real world challenges - open-ended, complex problems with incomplete data that require pruning of alternatives.

Note that the term "case study" has been used to mean a variety of different things by different practitioners. There is a large body of literature on using "cases" for the purpose of student instruction, primarily in the disciplines of business and law, but more recently in the engineering literature ${ }^{1,2,3}$. In this context, "cases" are brief (1-2 page) descriptions of an actual problem. Students are challenged to analyze the situation and formulate a response, taking into consideration all of the facets of the open-ended problem. Another type of "case study" is really a short (1-5 page) problem statement which identifies the product or process, the design basis, associated process constraints or specifications, assumptions, and required deliverables. Several recent chemical engineering design textbooks ${ }^{4,6,7}$ contain text or accompanying CD versions of design problem statements. Our concept of a case study involves not only the problem statement,

\footnotetext{
"Proceedings of the 2004 American Society for Engineering

Education Annual Conference \& Exposition

Copyright ( ) 2004, American Society for Engineering"
} 
but associated tutorials and solution information that provide an introduction to the material, both for the students and for the mentoring faculty.

The formulation of design projects for a capstone design class is in and of itself a constrained design problem since the semester is only 15 weeks in duration. This presents three major challenges; the project expectations must be challenging yet attainable, the scope must encompass the essence of industrial practice and represent a realistic situation, and possibly most challenging to the instructor, the technical focus of the topic must be such that the project advisor (usually the faculty member responsible for the course) is able to provide adequate guidance, support material, and mentorship to the students.

For this project the first objective was met by using design projects completed by previous years' design groups. The final reports were then compiled and the best sections or portions of the solutions condensed into a single exemplary solution. Following a review of the "solution", sections deemed incomplete were made part of the deliverables assigned to subsequent year's project team. This is not to imply that the solution presented is the only reasonable solution available. As with all engineering projects, many solutions can be considered viable and the students are encouraged to think creatively when determining a solution.

The second objective was realized through the involvement of industry professionals in the formulation of the design problem and the mentoring of the teams responsible for the project report. These practitioners have also been involved in the review of the solution material and have provided additional suggestions for the completion of the case study materials. For example, because of the novelty of the biotechnology-related projects, much of the initial solution material generated by student groups focused on material that was new to chemical engineering practice, i.e. validation protocols for equipment, inoculation and cell cultivation, and biomass processing. The solutions lacked basic engineering data for equipment sizing, utility usage, and thus were vague on how production costs were actually calculated. This year's students will be addressing these issues and their results will be added to the support material for each exemplary solution.

The case study represents our effort to address the third challenge. Some Chemical Engineering faculty members may need support for the biotechnology projects if they lack practical experience in this field. At NCSU we are fortunate to have faculty with biochemical engineering expertise as well as industrial mentors through the local ISPE (International Society of Pharmaceutical Engineering) chapter, with NCSU students also having access to internships with local pharmaceutical companies and manufacturers. The industrial mentors supplied by ISPE were especially helpful in the development of the information for the two biotechnology case studies.

\section{Case Study Structure}

To simplify the accessibility of the case studies, the information contained on the websites and the websites themselves are structurally similar. The case study information can be broken up into three major components:

1. Problem statement

2. Support Information

3. Exemplary Solution

"Proceedings of the 2004 American Society for Engineering

Education Annual Conference \& Exposition

Copyright ( ) 2004, American Society for Engineering" 
The problem statement contains the basic information that the student would need to get started on the project. The general purpose of the project, raw material specifications, basic operating parameters and systems, reaction kinetics, and product specifications are included in this section.

Support information includes a list of starting references, tutorials on relevant processes (created by previous years' project teams), facility layouts, equipment lists, and suggested deliverables for the project teams. The exemplary solution provides a complete project report, including an executive summary, introduction, technical background, process description, waste management plan, regulatory review, facility design, validation/commissioning plan, detailed manufacturing costs, detailed spreadsheet calculations for material balances, equipment sizing, utility usage, profitability analysis, and process simulation results.

\section{Case Study Access and Example}

The structure of the website, and exemplary material based on the co-protein project, will be presented to illustrate the nature and detail of the case studies developed for the website. The reader should keep in mind that this is not "web-based instruction" but rather a source of instructional material which can be accessed via the web. While this material may be adapted to a web-based instructional scenario, this would be the responsibility of the faculty implementing this material.

Students and faculty can access all of the case studies from the main page of the website (http://www2.ncsu.edu:8010/unity/lockers/project/actionagenda/coprotein/). The website will be divided into two levels of access: Student and Faculty. Students will have access to descriptive information about the project and essential technology, as illustrated in the figure below. Faculty will have access to all of the same information as students; in addition, the exemplary solution will be available through a password-protected protocol. The instructor will request password access through an on-line registration page marked "Instructor" on the main page, and will then be provided with email addresses for the authors. The authors will solicit feedback from faculty utilizing these cases regarding questions, problems, or suggestions for additional material to be included. This feedback will be used to improve the case study materials. 


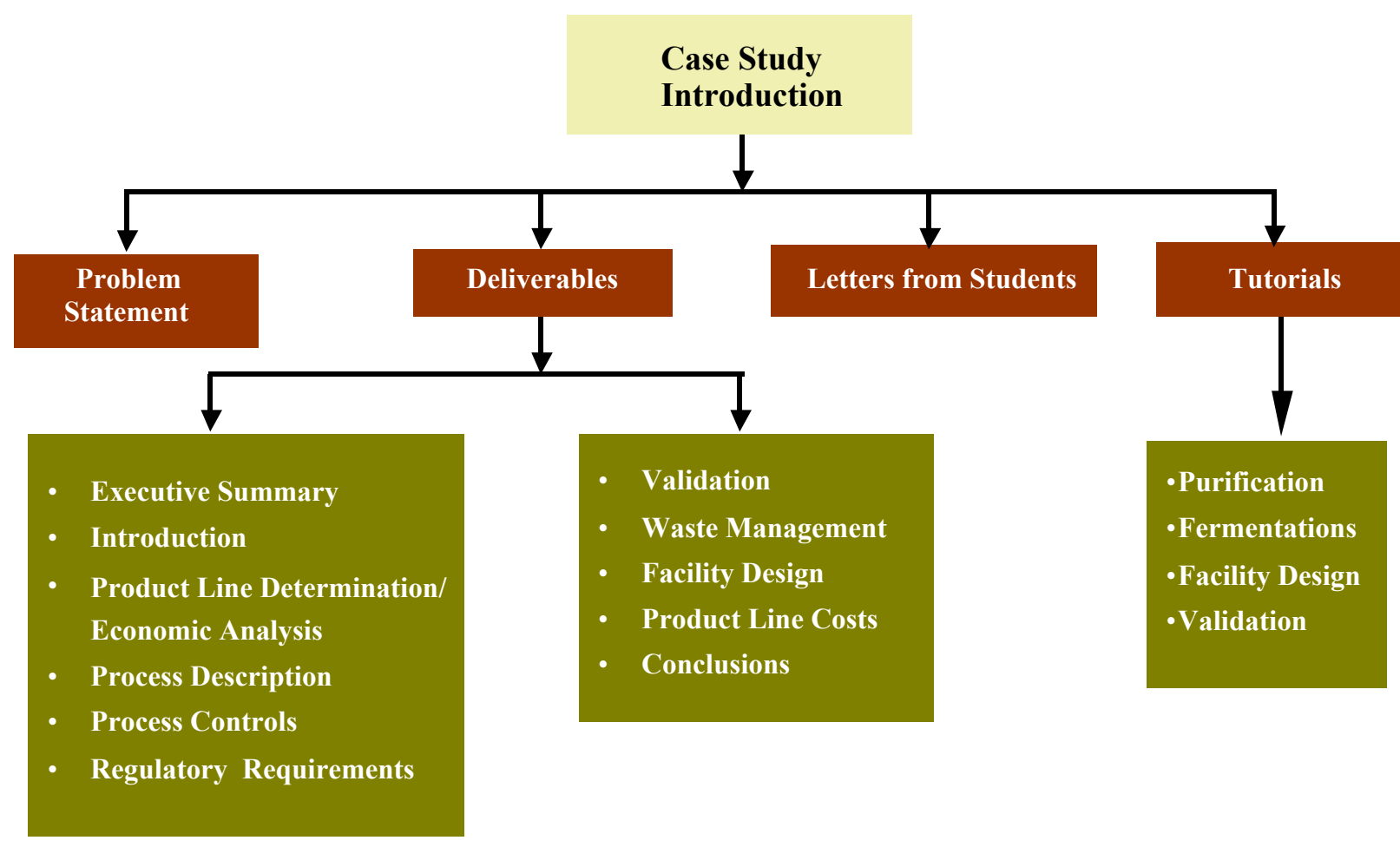

\section{Case study information: Co-protein}

Examples of the problem statement, list of deliverables, student letters, and tutorials are described next, to indicate the organization and ease of comprehension of the website.

\section{Problem Statement and Deliverables (associated figures and tables omitted for brevity)}

The problem statement is fairly detailed, given that most CHE students have little experience with biological systems, and that the proteins and processes described are "disguised" so as to avoid disclosure of proprietary information on the part of the original project sponsor.

PeptiVax Inc., a biotechnology company, has developed several co-proteins that may help in the fight against several common viral diseases. In test animals, each co-protein attaches to a target virus and the virus-protein complex stimulates the production of antibodies against the virus. This cooperative system may also enable the human body to produce a small amount of antibodies that will limit the spread of the virus. Several of these antigenic "co-proteins", co-Hep B, co-Hep C, co-Human Papilloma Virus, co-RSV, co-Rotavirus, and co-HIV, are now in Phase I clinical trials (see Table 1 [contained on the web site] for protein characteristics). The management of PeptiVax Inc. would like your group to evaluate and recommend a proposed product line, design the corresponding Escherichia coli based processes for protein production (see Table 2 [contained on the web site] for $E$. coli growth data), and determine the required modifications to their existing facility (see Figure 1 [contained on the web site] and Tables $3 \& 4$ [contained on the web site]).

PeptiVax's senior management would like to see the following information and deliverables:

* United States Target Market and Market Size

* Intermediate and Final Product Descriptions

* Major Regulatory Requirements of the US market

* ROM Project and Product Cost

* Process Summaries

* Descriptions of all Facility Modifications

"Proceedings of the 2004 American Society for Engineering Education Annual Conference \& Exposition Copyright $\left({ }_{0}\right.$ 2004, American Society for Engineering" 
* Capacity and Annual Schedule, Based on Market Potential

* Preliminary Design/Construction/Validation/Regulatory Schedules

PeptiVax's technical \& regulatory personnel would like to see the following:

* Process Flow Diagrams (PFD's)

* Process Description

* Material Balances (Raw Materials, Product, Waste, etc.)

* Equipment Lists, with Specifications

* Control System Requirements (new systems)

* Facility Floor Plan, Indicating Material/Personnel Flows

* Utility Requirements

Product line proposals should be accompanied by an economic analysis of the potential market value of each co-protein. This should include a detailed description of the corresponding viral infections combated by each co-protein, and the current United States infection rates. The design process for any proposed product line should be based on the assumption that all the co-proteins are produced extracellularly by a specialized strain of the recombinant host organism, Escherichia coli. Each recombinant strain of E. coli will be able to produce one and only one of the potential co-proteins. The individual co-protein characteristics are presented in Table 1 [contained on the web site]. Keep in mind that the required modifications to the existing PeptiVax facilities should take into account the amount of each co-protein needed to capture the desired market share over the course of one calendar year.

This is the information deemed sufficient for the design team to understand the needs of the project sponsor. This section is followed by the table of contents for the project deliverables, shown next.

\author{
Student Deliverables: \\ Table of Contents \\ 1. Executive Summary \\ 2. Introduction \\ 3. Product Line Determination/Economic Analysis \\ 4. Process Description \\ 5. Process Controls \\ 6. Regulatory Requirements \\ 7. Validation \\ 8. Waste Management \\ 9. Facility Design \\ 10. Detailed Costs of Proposed Product Lines \\ 11 Conclusions
}

Each item in the table of contents is a link to a page in the website that contains a brief (1-2 paragraph) definition/explanation of that item. For example, the Process Description link will take you to a page with the following information:

\title{
What is expected:
}

The economic analysis performed above gives upper management at Pepti-Vax enough information to determine what drugs should be produced. This is based on the anticipated market capture and on approximating the cost of producing a recombinant drug. However, the numbers generated are rough estimates. In order to calculate a detailed manufacturing cost and to design the facility to accommodate the equipment necessary for the production of these co-proteins, the specific manufacturing process for each co-protein is required. Before a specific process can be developed, it is necessary to understand the different equipment that can be used in a

"Proceedings of the 2004 American Society for Engineering

Education Annual Conference \& Exposition

Copyright (C) 2004, American Society for Engineering" 
biotechnology process. This information can then be used to streamline the process by utilizing the minimum number of unit operations required for each co-protein production. To be included in this deliverable are:

- Overall description of protein production process

- Complete process block flow diagram

- Unit operation descriptions of each process unit

- Material and Energy Balance

Need more help on Fermentation and Purification overviews?

See the Fermentation and Purification tutorials in the Resources section.

The explanations are sufficiently general to allow further refinement by the individual instructor but sufficiently details to allow the team to begin work on the item in question. There are also links to relevant tutorials through the Resource main page.

\section{Letters from Students}

This section contains letters from former design teams with advice regarding project management, preparing oral and written presentations, and general words of encouragement. A brief example regarding oral and written presentations is shown below:

Recommendations \& Lessons Learned from Co-Protein 1 Group (2002) (taken directly from student comments)

Written

1. Create outline for proposal and phase reports before actually writing.

2. Don't underestimate the importance of writing versus technical content.

3. Get connected with technical advisors and use to full advantage.

4. Schedule regular meetings with advisor.

5. Schedule regular weekly or biweekly meetings with group.

6. Get outside English teacher or use technical writing advisor to review all reports.

7. Set goal to complete technical aspects of report the week before due date, so that the last week may focus on writing quality (i.e. grammar, sentence structure, etc.)

8. In group meetings, wither (sic) before or after each phase has been completed, discuss each person's section. Each person should have a thorough understanding of everything in the report, including all assumptions made and all calculations.

9. Use reader's comments from each phase, to build on them for the next phase.

10. Choose a project that you have sincere interest in. This will help keep you motivated and interested throughout the semester.

11. Don't get discouraged - everything comes together.

12. There is no "real" structure and requirement fort (sic) what is to be included in the final project - it really depends on how you got there.

13. Do not look for specific outline of what needs to be done when starting project - start on your own and think of what seems reasonable to accomplish.

Oral Presentation

1. Transition between every slide.

2. Go over "pretend" responses to question and answer period - be prepared for questions (or how to respond to questions) you do not know.

3. Request to go first.

4. Don't use white background - always use blue.

5. Make sure that all figures and tables are legible. If this is not possible, make handouts for everyone to see.

6. All group members presenting should stand.

"Proceedings of the 2004 American Society for Engineering

Education Annual Conference \& Exposition

Copyright ( ) 2004, American Society for Engineering" 
7. Practice, Practice, Practice.

8. Assign each person responsible for every section of the presentation so that they can field questions. This will prevent confusion and looks of helplessness during the question and answer session.

While much of this advice is identical to that which the professor would give, there is added validity when it comes from the mouth (or pen) of a peer!

\section{Tutorials and other Resources}

The Resources link from the main page takes the students to a list of references (web sites, tutorials, books, and professional journals) that will help them get started on uncovering the technical background for their project. The resource page for the co-protein project is summarized below.

Co-Protein Case Study Resources

web resources | tutorials | texts and books | journals/professional magazines

Web Resources (these are links to other parts of this page)

Center for Disease Control Hepatitis Information Page

http://www.cdc.gov/ncidod/diseases/hepatitis/index.htm

MedicineNet.com http://www.medicinenet.com

HIVandHepatitis.com

http://www.hivandhepatitis.com/\#hepc/tmhepc.html

Center for Disease Control Rotavirus Information Page

http://www.cdc.gov/ncidod/dvrd/revb/gastro/rotavirus.htm

Center for Disease Control Human Papillomavirus (HPV) Information Page

http://www.cdc.gov/nchstp/dstd/HPVInfo.htm

The Respiratory Syncytial Virus Info Center http://www.rsvinfo.com

American Lung Association RSV information

http://www.lungusa.org/diseases/rsvfac.html

Center for Disease Control HIV/AIDS Information Page http://www.cdc.gov/hiv/dhap.htm

\section{Tutorial Help}

Please Note:

* PPT denotes a PowerPoint file. This will open in Internet Explorer or Microsoft PowerPoint.

* PDF denotes an Adobe PDF file. This requires Acrobat reader.

Overview of Fermentation (ppt) (pdf)

Overview of Purification (ppt) (pdf)

Validation Tutorial (ppt) (pdf)

Overview of Facility Design (ppt) (pdf)

\section{Books and Texts:}

"Proceedings of the 2004 American Society for Engineering

Education Annual Conference \& Exposition

Copyright ( ) 2004, American Society for Engineering" 
Bailey, J.E. and D. F. Ollis, Biochemical Engineering Fundamentals, 2nd ed., McGraw-Hill Book Co., New York, 1986.

Shuler, M. L. and F. Kargi. Bioprocess Engineering Basic Concepts, 2nd ed., Prentice Hall, Upper Saddle River, NJ , 2002.

\title{
Journals/Professional Magazines:
}

Pharmaceutical Manufacturing, PutmanMedia www.pharmamanufacturing.com

Chemical Processing, PutmanMedia www.chemicalprocessing.com

CONTROL for the process industries, PutmanMedia www.controlmag.com

Note that the tutorials are available in both PowerPoint and PDF formats.

\section{Summary}

Three case studies are under development and continuous improvement, and are being verified internally. All of the case studies are current projects this semester, and we expect to add to the material on the website at the end of this semester. The projects are not currently being mentored by someone knowledgeable in the relevant technical areas, so this will be a test of the utility of the resource material provided to the students. The case studies will be offered to the wider community at the end of summer 2004.

\section{BIBLIOGRAPHY}

1. Fitzgerald, N., "Teaching With Cases," ASEE Prism, Vol. 4(7), 16-20, 1995.

2. Henderson, J.M., L.G. Bellman, and B.J. Furman, “A Case for Teaching Engineering with Cases,” J. Eng. Education, 288-292, Jan. 1983.

3. Herreid, C.F., "What Is A Case? Bringing to Science Education the Established Teaching Tool of Law and Medicine," J. College Science Teaching, 92-23, Nov. 1997.

4. Peters, Max S., Klaus D. Timmerhaus, and Ronald E. West, Plant Design and Economics for Chemical Engineers, Fifth Edition, McGraw Hill, 2003, pp. 900-905.

5. Rousseau, Ronald W. and Robert C. Armstrong, "New Directions and Opportunities - Creating the Future," Workshop on Frontiers in Chemical Engineering Education, AIChE National Meeting, San Francisco, CA, November 2003.

6. Seider, Warren D., J.D. Seader, and Daniel R. Lewin, Product and Process Design Principles, Second Edition, John Wiley \& Sons, Inc., 2004, pp. 782-783.

7. Turton, Richard, "A Variety of Design Projects Suitable for Sophomore, Junior, and Senior Courses," Retrieved March 9, 2004 at http://www.che.cemr.wvu.edu/publications/projects/index.php

\section{BIOGRAPHICAL INFORMATION}

\author{
"Proceedings of the 2004 American Society for Engineering \\ Education Annual Conference \& Exposition \\ Copyright ( ) 2004, American Society for Engineering"
}




\section{LISA G. BULLARD}

Lisa G. Bullard received her BS in ChE from NC State and her Ph.D. in ChE from Carnegie Mellon. She served in engineering and management positions within Eastman Chemical Co. from 1991-2000. At N.C. State, she is currently the Director of Undergraduate Studies in Chemical Engineering.

\section{PATRICIA K. NIEHUES}

Patricia received her BS in ChE from NC State in 2001. She has 11 years of process control and design experience in the specialty chemicals industry with DuPont and Degussa. She has served as a coach for senior design groups at NC State for the past four years.

\section{STEVEN W. PERETTI}

Steven W. Peretti is an Associate Professor of Chemical Engineering at NC State. He has directed research in bacterial protein synthesis, bioremediation, gene transfer in biofilms, and green chemistry applications of bioconversion processes. Recently, he has become active in the areas of cross-disciplinary education and service learning.

\section{SHANNON H. WHITE}

Shannon H. White received her M.Ed from N.C. State University and is working on her Ph.D. in Curriculum and Instruction. She has worked in traditional and non-traditional educational settings since 1995. At N.C. State University, she has worked as a designer and consultant on a number of instructional multimedia projects, websites, and publications. 